\title{
The Collaborative Strategy between Facilities Management and Organizational Behaviour for Quality Business Performance in Malaysia
}

\author{
Maszuwita Abdul Wahab ${ }^{1}$, \\ ${ }^{I}$ Department of Estate Management, Faculty of Architecture, Planning \& Surveying, \\ University Teknologi MARA
}

\begin{abstract}
Facilities Management (FM) is a prominent field with practitioners in many countries. In Malaysia, $F M$ is still at an early stage of development, and there is a need for greater awareness of the complementary role FM can play in supporting the core business of organizations. This paper presents the importance of human skills for FM to strengthen the business goals towards business efficiency. A qualitative approach was embraced to determine the level of thinking from the FM expertise towards adopting Organizational Behaviour $(O B)$ that have been identified through a critical literature review for a collaborative strategy. This approach was conducted through semi structured interview within fifteen (15) FM expertise. The responds will be presented in a tabular form by using coding system to foresee the level of improvement in the FM role precisely. This paper concluded that there is integration between FM and $O B$ to improve the current situation by upgrading the human skills for better performance. The limitation of this study is conducted throughout Malaysia to foresee the issues involves in FM field and focuses on human skills to remedy the current situation. Findings of this paper benefit the professionals to improve their human skills, to strengthen the productivity of the core business as well as to upgrade the supporting activities as a means to achieve business goals. This paper could also benefit educational institutions and encourage them to revise their FM syllabus and to produce quality professionals in the future.
\end{abstract}

Keywords: Facilities Management, Organizational Behaviour, Strategies, Quality and Performance

\section{Introduction}

Facilities Management (FM) is a multidisciplinary field that is increasingly popular and has been broadly applied in the United Kingdom, the United States and other developed countries. FM practices in the United Kingdom and the United States are very well focused to achieve core business objectives by producing quality products and services which provide value for money, increase customer satisfaction index, increase work productivity, increase the stability of the business environment and also increase the profit margin of an organization (Maszuwita and Kamaruzzaman, 2014). Besides, FM is a form of management involving various disciplines that contributes to the core business of organizations that sustains the support services to enable them to achieve continuous improvement in business. It is an important profession nowadays that highlights business strategies, innovation, finances, and people (human resources) to upgrade the recognition of the identity and image of FM (Maszuwita et.al, 2014). FM focuses on four important components consisting of place, people, process and technology (IFMA, 2010). These components integrate within one another to achieve the goals and objectives to meet strategy needs and to provide quality services. FM in Malaysia was assessed to be at the infancy level and required a quality provision to upgrade the FM field in the future. On the other hand, Pillay (2002) which was summarized in Kamaruzaman et al. (2010) briefly discussed the history of FM in Malaysia. The FM field started in the 1990s with the support given by government sector and was established in 1996. This was the stepping stone for Malaysia to develop FM more broadly. It is known that earlier, FM had less collaboration with the real estate, architecture, and construction professions, but now FM has a new level of thinking and collaborates with all these fields in order to strengthen the efficiencies of organizations that focus on people and process, as well as the FM indicators of time, cost and quality (Kamaruzaman et al. 2010). Therefore, it is important that transformation strategies for FM be spread throughout every organization that practices FM in Malaysia. This will help the organization to focus at each management level, including strategic level, tactical level and operational level. Prior to this, OB will be adopted in this study to foresee the improvement in the FM role more precisely and the most important resources in an organization are the human capital to support the business goals. Therefore, there is a need for transformation strategies in FM to expand the competences of FM organization in the global marketplace. 


\section{Literature review}

Table 1 lists the stages in a short history of FM that charts its evolution from the 1970s to the 2000s. It is important to see the development and the evolution in the FM industry in order to ensure continuous success in this field. It can be seen that in the field of FM is very broad and FM managers need to be aware of the knowledge chain in order to produce a quality organization and deliver quality services that fulfill the customers' expectations. To integrate the managerial level, OB is significant to constantly upgrade their skills for business success and business globalization. In this paper, elements of OB is divided into two (2) which are competitive skills and organizational environment -fit. The integration of FM and OB are very important to develop the best practices and to achieve the collaborative strategy for continuous improvement. Managers need to be responsible and practice management theory to influence the behaviour and performance of managers as well as manage according to the situational demands to achieve organizations' goals. In today's scenario, the collaboration of strategic, tactical and operational level is very significant to increase the productivity of organizations (Maszuwita et.al, 2014). Nutt (2000) focused FM as a strategic view that will add value to increase and achieve the potential outcomes. He had also mentioned that the strategic objective of FM "is to provide better infrastructure and logistic support to business and public endeavors of all kinds and across all sectors". This generic model will be a guideline for the FM organizations to upgrade their best practices that will lead to business success and innovation in their organizations respectively. Nutt (2000) had introduced a model entitled the generic trails to future that consist of four competing futures for FM which are business, people, property and information and had also illustrated the generic trails that contribute to productivity, human effectiveness and facilitating business success that has been illustrated in Figure 1.

Table 1: Short History of FM Development

\begin{tabular}{|l|l|c|}
\hline $\begin{array}{l}1970 \mathrm{~s} 1^{\text {st }} \\
\text { Generation }\end{array}$ & Managed services, outsourcing total FM & Operational \\
\hline $\begin{array}{l}1980 \mathrm{~s} \\
2^{\text {nd }} \text { Generation }\end{array}$ & Quality Management, integrated FM processes & Tactical \\
\hline $\begin{array}{l}1990 \mathrm{~s} \\
3^{\text {rd }} \text { Generation }\end{array}$ & Partnering, re-engineering process, knowledge management, product innovation, & Strategic \\
\hline $\begin{array}{l}2000 \mathrm{~s} \\
4^{\text {th }} \text { Generation }\end{array}$ & Bustainable FM & Transformational \\
\hline
\end{tabular}

Source: IFMA (2010)

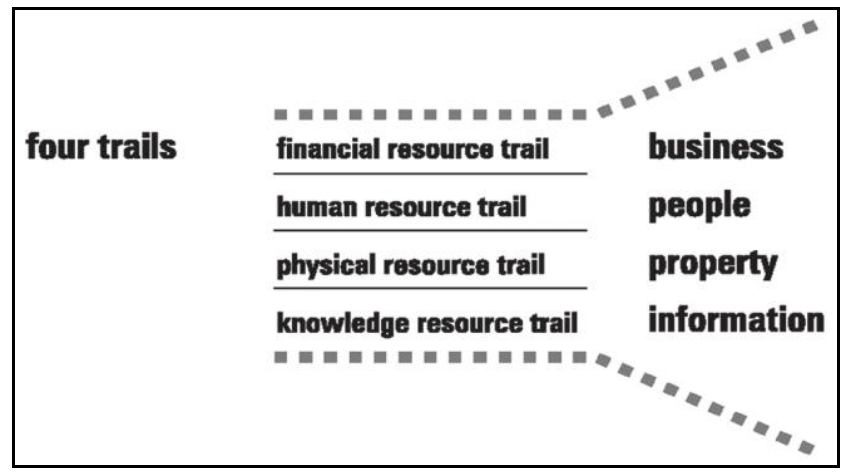

Fig 1: FM generic trails to the future (Nutt, 2000)

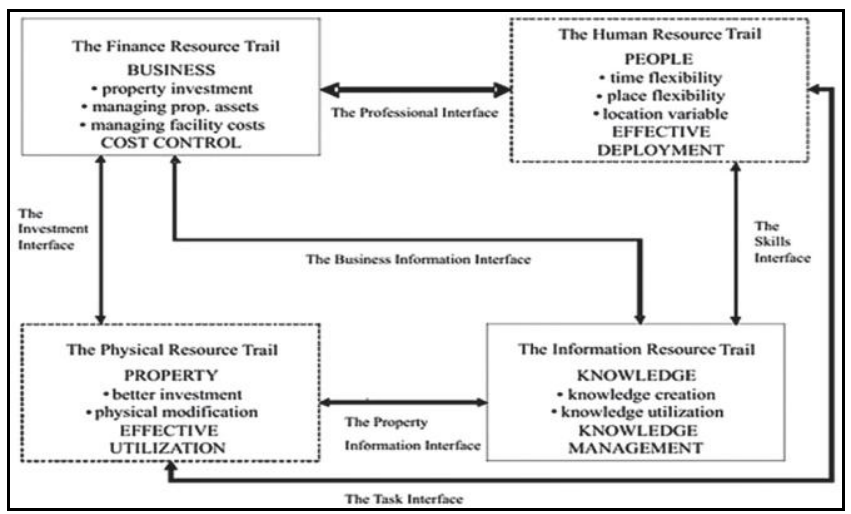

Fig 2: The resource model of strategic FM (Nutt, 2000) 
Figure 2 illustrated by Nutt (2000) with the interfaces that has been created by Grimshaw (2003) in order to have a better perspective for the FM profession in the future. These interfaces are significant to guide the FM managers to be quality professionals and focuses on the characteristic such as interpersonal, informational and decisional that supports the business objectives (Maszuwita et.al, 2014). To create an effective FM, organization need to have a strong leadership that covers quality human talent and plays an important phase in every organization to amplify the profit margin and business productivity in the future (Maszuwita et.al, 2014). Therefore the collaborative strategy within FM and OB are important to improve the efficiencies of FM gradually that will lead to innovation and business success towards the transformational environment.

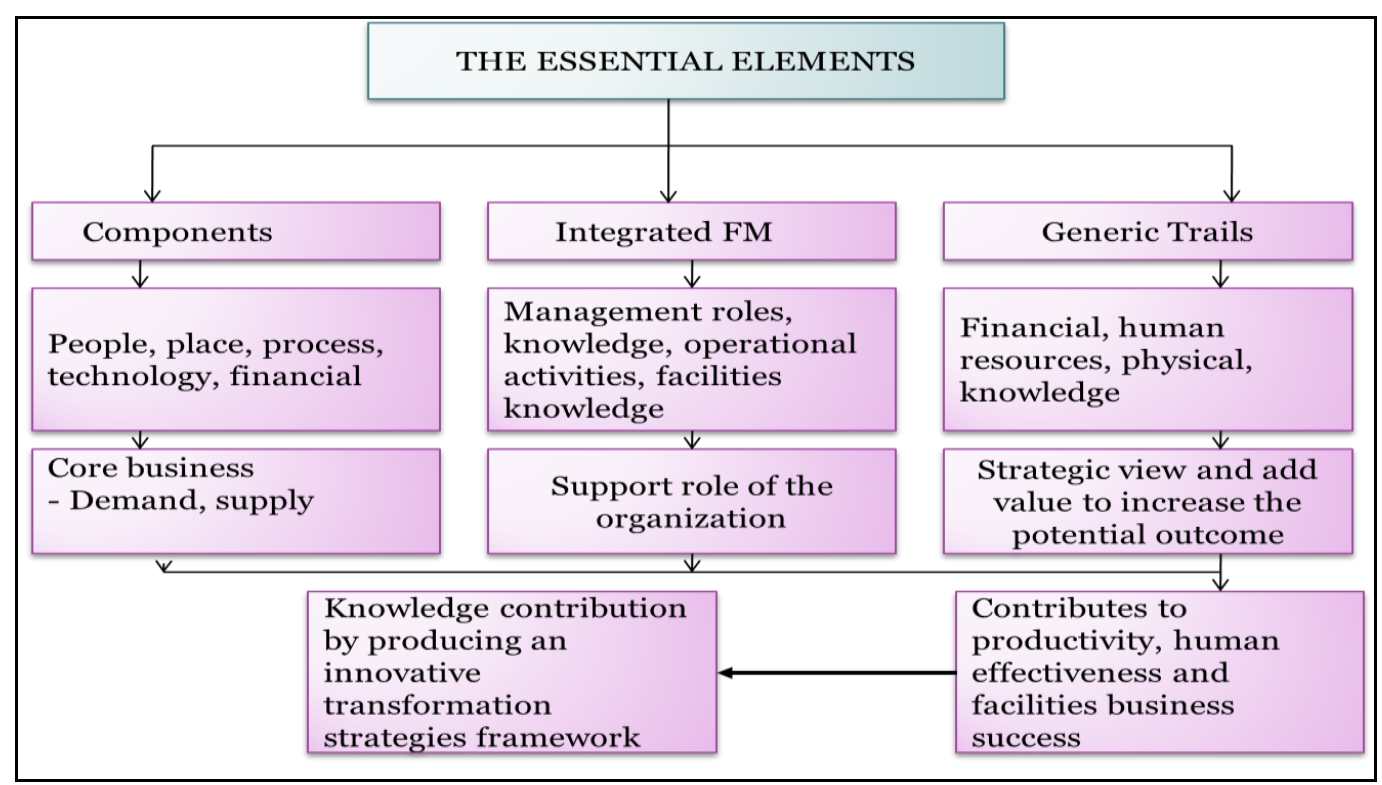

Fig 3: The essential elements for collaborative strategy

Figure 3 supports the statement that has been discussed in Table 1 for FM continuous improvement and shows the evidences through literature review from various researches. The essential elements are significant to foresee the FM future by looking into the human capital for business effectiveness as well as achieving organization goals. There is therefore a need for a collaborative strategy within FM and OB for better business outcomes and as a tool for FM globalization

\section{Methodology}

The objective of this paper is to foresee the integration of FM and OB for collaborative strategy. To achieve this objective, a semi-structured interview was carried out that focuses on the formal questions posed by the interviewer towards the respondents. FM experts were chosen as the respondents in this study throughout Malaysia. Each of them was given the same stimuli, so that the information collected from them can be differentiated accurately. In this section, fifteen (15) participants from senior and middle management were chosen for an optimum output. The participants from the senior management were coded as S1 to S8, and participants from middle management were coded M1 to M7.

\section{IV. findings and discussions}

Semi-structured interviews were carried out within a number of experienced facilities managers, property managers and academicians with FM background to identify and verify the issues involved in the FM field, and the impact of incorporating $\mathrm{OB}$ as preliminary data to develop guidance for future purposes. The impact of the semi-structured interviews with experts in the field of built environment was an important approach, whereby many FM issues were discussed and it became apparent that FM strategies would be needed to guide improvements in the present situation. The experts also mentioned that the development of FM strategies will help to lead to a quality organization and to accomplish success by achieving continuous improvement. The research findings, is presented by looking into the description given by the FM expertise that has been illustrated as follows. 
The Collaborative Strategy between Facilities Management and Organizational Behaviour for ..

\subsection{Facilities Management Performance}

Table 2: Characteristics of Facilities Management Performance

\begin{tabular}{|c|c|c|}
\hline Characteristic & Number of Participants & Descriptions by participants \\
\hline $\begin{array}{l}\text { FM Competency Area } \\
\text { (FMP1) }\end{array}$ & 15 & $\begin{array}{l}\text { - Produce essential skills } \\
\text { - FM will be practiced accordingly without any } \\
\text { misperception in FM task } \\
\text { - Integration within people and process }\end{array}$ \\
\hline $\begin{array}{l}\text { FM Quality } \\
\text { (FMP2) }\end{array}$ & 15 & $\begin{array}{l}\text { Ensure the FM quality by producing quality } \\
\text { services } \\
\text { Managing and maintaining support system to } \\
\text { increase the FM profit }\end{array}$ \\
\hline $\begin{array}{l}\text { Trails for FM Continuity } \\
\text { (FMP3) }\end{array}$ & 15 & $\begin{array}{l}\text { - Increase knowledge and human skills } \\
\text { - Prevent error for better FM }\end{array}$ \\
\hline
\end{tabular}

Table 2 shows the description given by the participants towards FM competency area, FM quality and trails for FM continuity. FM competency area, this relates to the necessity to ensure that technical, financial and management areas be practiced in FM for business globalization. Participant S2 mentioned that, "Skills and knowledge in competency areas need to be widely exposed to have the integration within process and people, as well as to avoid misperception of task in FM field". Meanwhile FM quality is focused on implementing the quality strategies such as quality control, quality improvement and quality assurance that will increase the level of FM performance. Participant S1 explained that "Providing quality services and managing the support system will increase the profit margin in FM business". Whereas the trails for FM continuity are significant to foresee the skills, knowledge, and practical experience which is important for a longer term commitment. Participant M1 explained that, "FM managers need to enhance their strategic, tactical and operational skills to achieve the continuous improvement in their business and to prevent errors for better quality in FM performance".

\subsection{Organizational Behaviour}

Table 3: Characteristics of Organizational Behaviour

\begin{tabular}{|lcl|}
\hline \multicolumn{1}{|c|}{ Characteristic } & \multicolumn{1}{c|}{$\begin{array}{c}\text { Number of Participants } \\
\text { (Data Validation) }\end{array}$} & \multicolumn{1}{c|}{ Descriptions by participants } \\
$\begin{array}{l}\text { Organization Environment } \\
(\mathbf{O E})\end{array}$ & 15 & $\begin{array}{l}\text { Growing realization that people either make or break } \\
\text { an organization } \\
\text { There is a need for leaders to understand their people } \\
\text { better }\end{array}$ \\
& & $\begin{array}{l}\text { Ready for a long term commitment } \\
\text { Increase organizational effectiveness }\end{array}$ \\
\hline Competitive Skills (CS) & - $\begin{array}{l}\text { Produce skilled FM personnel } \\
\end{array}$ & FM staff should be able to complete multiple tasks \\
\hline
\end{tabular}

Table 3 shows the description given by the participants towards organization environment and competitive skills. The organizational environment is needed to ensure that the magnitudes of challenges in workplace are managed effectively. Therefore, organizational process, team dynamics, foundation of employees, contemporary challenges and program development need to be considered for organizational growth (McShane et al.,2013). Participant S4 stated that, "Development of organization should include various initiatives as reference to their benchmarked success. However, strategic thinking and strategic direction will help to assess the competencies in organizational environment". Besides, competitive skills refer to the level of efficiencies in FM needed to produce skilled personnel who are able to complete multiple tasks. FM managers should focus on interpersonal, informational and decisional skills to support the organization development. Participant M2 mentioned that, "Choosing FM employees based on their results or performance appraisal itself is insufficient. FM employees need to be talented and ideal for steady growth environment and require commitment in terms of time, process, people, resources and financial."

\subsection{The Collaborative Strategy Between Facilities Management and Organizational Behaviour}

Table 4 shows the integration of characteristic within FM and OB to foresee the collaborative strategy in FM business. It is also important to increase the human quality in FM field for business efficiencies and effectiveness. Fifteen (15) participants had given their responds to encourage OE has a positive influence on FMP1, FMP2 and FMP3. OE focuses on the internal and external environments of an organization towards business continuity. Furthermore, organization effectiveness is concentrated on having good fit of resources that align with their external environment. Participant M4 highlighted that "OE is significant to create the changes 
that produce quality services and products as well as to create an efficient transformation process for future inputs." The integration of FM and OB has a strong influence towards business globalization where human capital plays an important role. Participant S3 and M3 mentioned that "People's behaviour and managerial support plays an important role in every organization's success by producing high quality services and products to achieve a prominent level of performance. Besides, OB is not only important for managers but also for anyone who works in an organization in order to manage themselves, and to work effectively with each other to gain business goals." Moreover, competitive skills are significant in every organization to discover opportunities for business best practices. Participant S5 commented that "Competitive skills helps to minimize threats and as an added value for organization effectiveness. Besides, human capital is important to deliver financial values to the organization system and provide relationships among internal customers, external customers, suppliers and others". Therefore, FM managers need to be aware of the management essential elements to support their management process and upgrade themselves towards business success.

Table 4: The Elements of f Facilities Management and Organizational Behaviour for Collaborative Strategy

\begin{tabular}{|c|c|c|}
\hline Characteristic & $\begin{array}{l}\text { Number of } \\
\text { Participants } \\
\text { (Data Validation) }\end{array}$ & Descriptions by participants \\
\hline $\begin{array}{l}\text { OE has a positive influence on FM } \\
\text { Competency Area (FMP1) }\end{array}$ & 15 & $\begin{array}{l}\text { Good fit of resources aligned with overall competencies will } \\
\text { have optimistic changes in their production. }\end{array}$ \\
\hline $\begin{array}{l}\text { OE has a positive influence on FM Quality } \\
\text { (FMP2) }\end{array}$ & 15 & $\begin{array}{l}\text { Good fit of resources will increase the level of performance } \\
\text { by anticipating change in the environment. }\end{array}$ \\
\hline $\begin{array}{l}\text { OE has a positive influence on Trails for } \\
\text { FM Continuity (FMP3) }\end{array}$ & 15 & $\begin{array}{l}\text { Good fit of resources will strengthen the overall business } \\
\text { and indicates an efficient transformation process for future } \\
\text { inputs }\end{array}$ \\
\hline $\begin{array}{l}\text { CS has a positive influence on FM } \\
\text { Competency Area (FMP1) }\end{array}$ & 15 & $\begin{array}{l}\text { Human capital is the main resource to discover organization } \\
\text { opportunities and minimize threats }\end{array}$ \\
\hline $\begin{array}{l}\text { CS has a positive influence on FM Quality } \\
\text { (FMP2) }\end{array}$ & 15 & Diversity of skills to manage the core business \\
\hline $\begin{array}{l}\text { CS has a positive influence on Trails for } \\
\text { FM Continuity(FMP3) }\end{array}$ & 15 & $\begin{array}{l}\text { Knowledge, skills and abilities will provide high levels of } \\
\text { efficiency and quality as added value for an organization. }\end{array}$ \\
\hline
\end{tabular}

\section{V. way forward}

The integration of FM and $\mathrm{OB}$ contributes to organization at every management level to increase the profit margin and to foresee the continuous improvement towards business success. By providing the right human capital, the innovative strategies that collaborates OB in FM will achieve the business goals to upgrade the effectiveness and efficiencies of FM organization for quality services and changes in FM industry can be an innovative way to achieve the business continuity and improve the image of FM organization respectively. Therefore, this integration plays an important role to increase the workforce diversity in FM field for business efficiencies and effectiveness.

\section{VI. conclusion}

This paper focused on how to improve the FM industry by looking into the human resource and to add value to the industry for competitive advantage. For this reason, OB was included to support future improved FM performance and contribute to changes in the industry. The significant elements of OB provided an important impact on FM performance for FM continuous improvement, FM effectiveness, FM efficiency and FM integration. Lack of strategic credibility will affect corporate knowledge and, therefore, business outcomes. Hence, FM managers should focus on human skills in order to be competent within global FM companies for longer term development. Prior to this, FM companies can achieve higher competency levels and as a clear intangible component in managing their FM business.

\section{Journal Papers}

\section{References}

[1] Grimshaw, R. W. Facilities Management: The Professional Interface. Facilities, 21(3/4), (2003). 50-57.

[2] Kamaruzzaman, S.N., \& Zawawi, E. M. A. Development of Facilities Management in Malaysia, Journal of Facilities Management, 8(1), 2010, 75-81.

[3] Maszuwita, A.W., Kamruzzaman, S.N., Ghani, M.K.. The Significance of Strategic Planning and Management. The Professional Journal of Institution Surveyors Malaysia. 47(2), 2012, 23-29. 
The Collaborative Strategy between Facilities Management and Organizational Behaviour for ..

[4] Maszuwita, A.W., \& Kamruzzaman, S.N. A Preliminary Review: Knowledge Chain for the Effective Facilities Management Strategies. Journal of Society for Development of Teaching and Business Process in New Environment in B\&H, 9(4), 2014, 404-809.

[5] Nutt, B. Four Competing Futures for Facilities Management. Facilities, 18(3/4), 2000,124-132.

[6] IFMA. Facility Management Trend Report. IFMA Foundation Survey, 2010.

\section{Books}

[7] McShane, S.L., \& Glinow, M.A.V.,Organizational Behaviour (New York: McGraw- Hill, 2013).

[8] Pillay, M.S. Privatisation of Hospital Support Services (Berlin: Springer,2002).

Theses

[9] Maszuwita Abdul Wahab, Transformation Strategies for Facilities Management in Malaysia, PhD, University of Malaya, Kuala Lumpur, Malaysia (2016). 